\title{
Rapid four-component synthesis of dihydropyrano[2,3-c]pyrazoles using nano-eggshell/Ti(IV) as a highly compatible natural based catalyst
}

\author{
Arefeh Dehghani Tafti ${ }^{1}$, Bi Bi Fatemeh Mirjalili ${ }^{1 *}$, Abdolhamid Bamoniri $^{2}$ and Naeimeh Salehi ${ }^{1}$
}

\begin{abstract}
Nano-eggshell/Ti(IV) as a novel naturally based catalyst was prepared, characterized and applied for the synthesis of dihydropyrano[2,3-c] pyrazole derivatives. The characterization of nano-eggshell/Ti(IV) was performed using Fourier Transform Infrared spectroscopy, X-ray Diffraction, Field Emission Scanning Electron Microscopy, Energy-Dispersive X-ray Spectroscopy, and Thermo Gravimetric Analysis. Dihydropyrano[2,3-c]pyrazoles were synthesized in the presence of nano-eggshell/Ti(IV) via a four component reaction of aldehydes, ethyl acetoacetate, malononitrile and hydrazine hydrate at room temperature under solvent free conditions. The principal affairs of this procedure are mild condition, short reaction times, easy work-up, high yields, reusability of the catalyst and the absence of toxic organic solvents.
\end{abstract}

Keywords: Dihydropyrano[2,3-c]pyrazole, Nano-eggshell/Ti(IV), Multicomponent reactions, Eggshell, Titanium tetrachloride, Natural catalyst

\section{Introduction}

One key-step toward green chemistry concerns on chemical transformations under solvent-free conditions $[1,2]$. Solvent free conditions often have lead to decrease reaction time, increase yields and easy work-up [3, 4]. Combining this condition with multicomponent reactions (MCRs) disclosed a particular opportunity for architecting of heterocyclic molecules in short time [5, 6]. MCRs play an essential role in combinatorial chemistry due to one-pot synthesis of various complex molecules, atom economy and effectiveness compared with single step reaction [7, 8]. For economic and environmental reasons, solvent free reactions were demonstrated to be an efficient method for the synthesis of chemical product in

\footnotetext{
${ }^{*}$ Correspondence: fmirjalili@yazd.ac.ir

1 Department of Chemistry, College of Science, Yazd University,

P.O.Box 89195-741, Yazd, I.R. of Iran

Full list of author information is available at the end of the article
}

a clean and safe conditions [9-11]. Dihdropyrano[2,3-c] pyrazoles (DHPPs) are important class of heterocycle componds because of their wide applications in medicinal and pharmaceutical chemistry [12]. Many of these properties are known for their anti-microbial [13], antiinflammatory [14], anti-cancer [15], bactericidal [16], molluscicida [17], and kinase inhibitory [18] activities. In the first report, DHPP was synthesized by a reaction between 3-methyl-1-phenylpyrazolin-5-one and tetracyanoethylene [19]. Recently, DHPPs have been synthesized via the reaction of hydrazine hydrate, ethyl acetoacetate, malononitrile, and aldehydes. Some catalysts have been used to develop the above mentioned reaction such as $\gamma$-alumina [20], glycine [21], ionic liquids [22], L-proline [23], imidazole [24], $\mathrm{I}_{2}$ [25], and trietheylamine [26]. In the recent years, heterogeneous catalysts, due to the high capability for recycling and reutility, have surpassed homogeneous catalytic systems, despite their benefits 


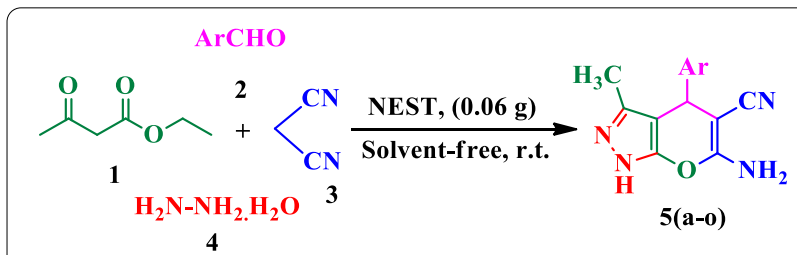

Scheme 1. Synthesis of dihydropyrano[2,3-c]pyrazoles catalyzed by nano-eggshell/Ti(IV)

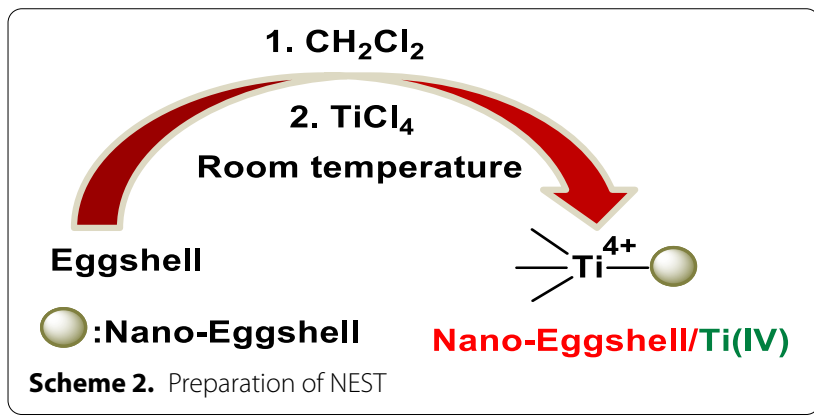

such as high activity and selectivity [27]. Nowadays, nanocatalysts have been subjected of immense interest, because of their potential applications in different fields. They have several important advantages as heterogeneous catalysts including high catalytic activity, readily available, simple separation, high degree of chemical stability, and reusability [28-31].

The eggshell is represented $11 \%$ of the total weight of the egg and composed predominantly of calcium carbonate (94\%), organic materials (4\%), calcium phosphate (1\%), and magnesium carbonate (1\%) [32].

In continuation of our previous works in using solid acid catalysts [33-38], herein, we reporte an efficient one-pot four-component reaction protocol for the synthesis of DHPPs in the presence of nano-eggshell/Ti(IV) (NEST) as a highly effective nanocatalyst in good to excellent yields under mild conditions (Scheme 1).

\section{Results and discussion}

\section{Characterization of the nanocatalyst}

NEST was prepared simply via addition of $\mathrm{TiCl}_{4}$ to a suspension of eggshell nanoparticles in $\mathrm{CH}_{2} \mathrm{Cl}_{2}$ (Scheme 2). The obtained catalyst was characterized using Fourier Transform Infrared (FT-IR) spectroscopy, X-ray Diffraction (XRD), Field Emission Scanning Electron Microscopy (FESEM), Energy-Dispersive X-ray (EDX) spectroscopy, and Thermo Gravimetric Analysis (TGA).

The FT-IR spectra of $\mathrm{CaCO}_{3}[39,40]$, nano-eggshell, and NEST are shown in Fig. 1. Distinct absorption bands can be observed at 711, 871, and $1391 \mathrm{~cm}^{-1}$ in all compared spectra show the presence of high percentage

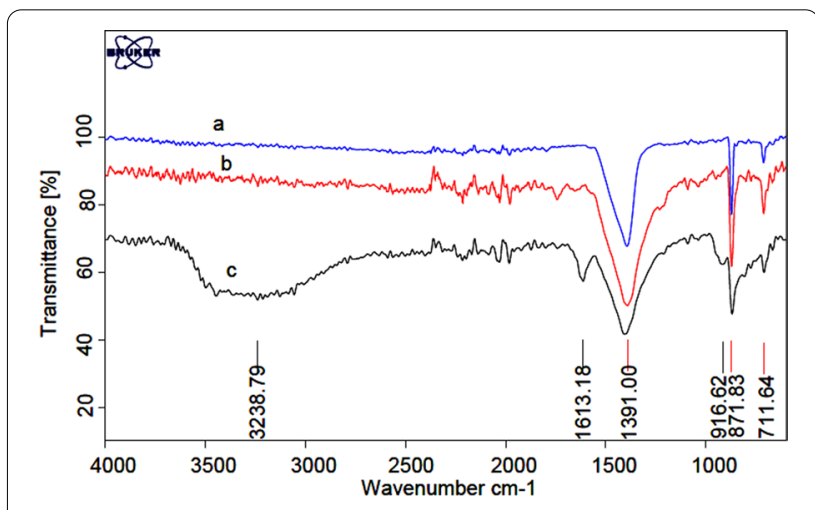

Fig. 1 FT-IR spectra of $\mathbf{a} \mathrm{CaCO}_{3}$, $\mathbf{b}$ nano-eggshell, and $\mathbf{c}$ NEST

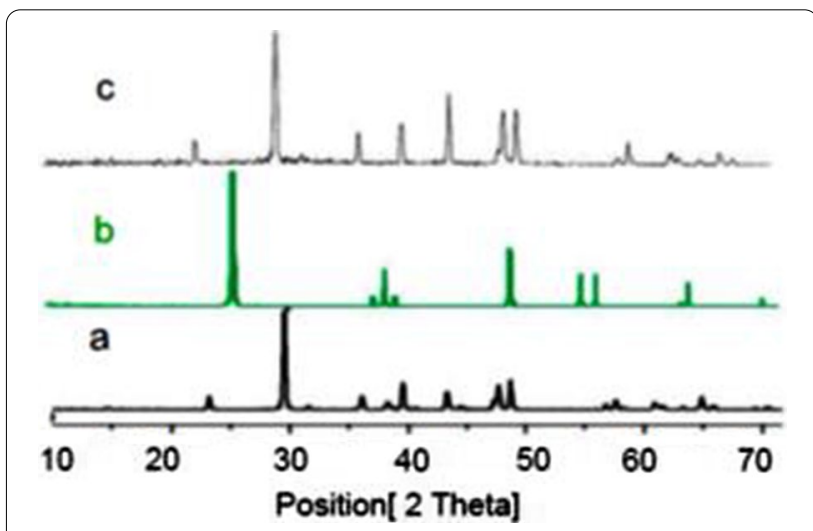

Fig. 2 The XRD patterns of $\mathbf{a} \mathrm{CaCO}_{3}, \mathbf{b} \mathrm{TiO}_{2}$, and $\mathbf{c}$ NEST

of $\mathrm{CaCO}_{3}$ in eggshell and NEST. For NEST (Fig. 1c), in addition to the eggshell absorption bands, stretching vibrations of $\mathrm{C}-\mathrm{O}-\mathrm{Ti}$ group at $780 \mathrm{~cm}^{-1}$ (according to previously reported FT-IR about $\mathrm{Ti}(\mathrm{OBut})_{4}$ [41, 42]) was appeared, indicated that $\mathrm{TiCl}_{4}$ have functionalized on nano-eggshell successfully. The absorbed band at $1613 \mathrm{~cm}^{-1}$ is associated to the bending vibration of $\mathrm{H}-\mathrm{O}-\mathrm{H}$ which have shown the absorbed water on catalyst [43].

Figure 2 shows the XRD patterns of $\mathrm{NEST}, \mathrm{TiO}_{2}$ and $\mathrm{CaCO}_{3}$ in the range of $10-70^{\circ}(2 \theta)$. NEST (Fig. 2c), has shown diffraction peaks at $2 \theta=23,29,37,40,43,47$, $48,56,57,61$ and $62^{\circ}$, which are quite matched with the structure of pure $\mathrm{CaCO}_{3}$. By comparison with Fig. 2a-c, we can conclude the absence of $\mathrm{TiO}_{2}$ and the presence of $\mathrm{CaCO}_{3}$ in catalyst.

Surface morphology of nano-eggshell and the synthesized NEST was observed using FESEM analysis (Fig. 3a, b). The FESEM image of NEST (Fig. 3b) indicates that morphology of the nano particles has a quasi-spherical shape. The average size of NEST was estimated about $40 \mathrm{~nm}$. 


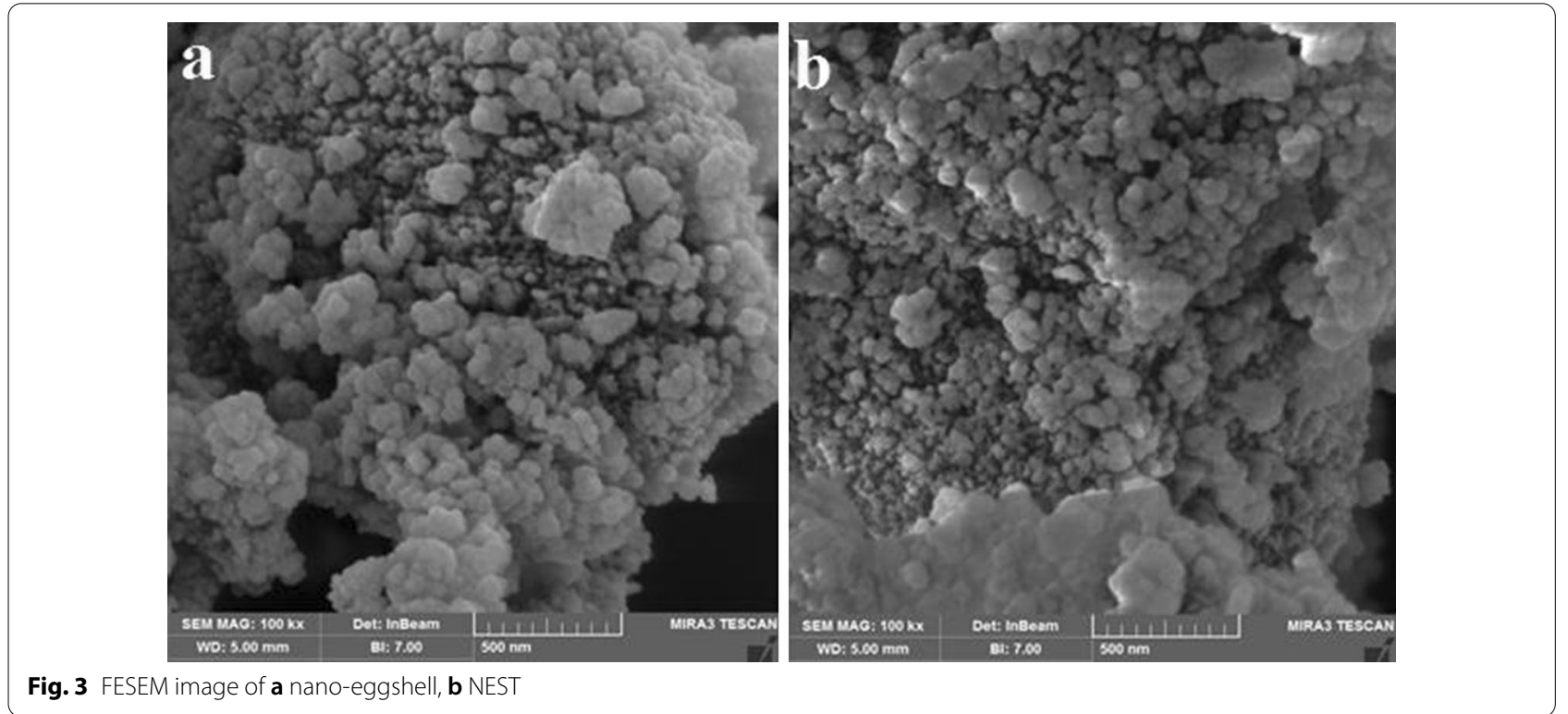

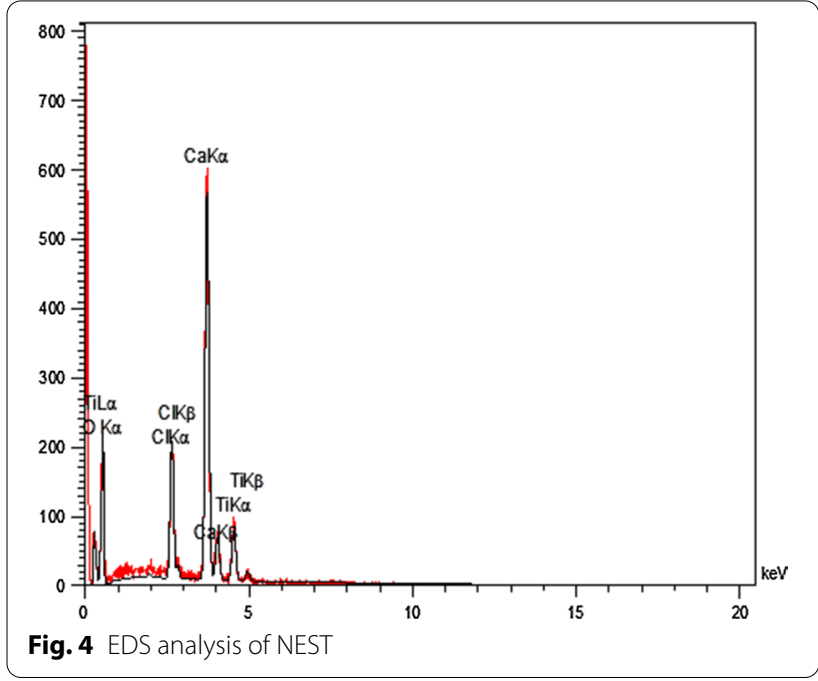

The existence of expected elements in the structure of the NEST was approved by EDX analysis (Fig. 4). The EDX results have clearly confirmed the presence of $\mathrm{C}, \mathrm{O}$, $\mathrm{Cl}, \mathrm{Ca}$ and $\mathrm{Ti}$ in the catalyst. According to this data, the weight percentages of the above-mentioned elements are $14.48,43.13,7.16,29.30$ and 5.94, respectively.

For thermal stability investigation of the catalyst, TGADTA analysis was done in a range of $45-813{ }^{\circ} \mathrm{C}$ (Fig. 5). The first decrease of weight was assigned to the catalyst moisture removal (endothermic effect at $70-130{ }^{\circ} \mathrm{C}, 4 \%$ weight loss). The second weight loss (16\%) was occurred at $130-600{ }^{\circ} \mathrm{C}$ with an exothermic process. As the temperature increased to $800{ }^{\circ} \mathrm{C}$, the main mass loss could

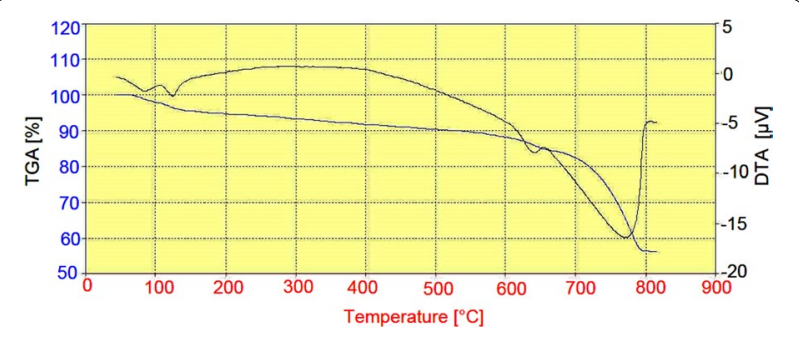

Fig. 5 TGA and DTA patterns of NEST

be associated with the decomposition of eggshell to $\mathrm{CO}_{2}$ and $\mathrm{CaO}$.

To optimize the conditions for the synthesis of the DHPPs in the presence of NEST, the condensation of 4-chlorobenzaldehyde, malononitrile, ethyl acetoacetate, and hydrazine hydrate in the molar ratio 1:1:1:2 was done under various conditions (Table 1). According to the obtained data, the best yield of 6-amino-4(4-chlorophenyl)-3-methyl-1,4-dihydropyrano[2,3-c] pyrazole-5-carbonitrile (5h) was achieved using $0.06 \mathrm{~g}$ of NEST at room temperature under solvent-free condition (Table 1, entry 12).

After optimization of the reaction conditions for preparation of DHPPs, various aromatic and heteroaromatic aldehydes were used for expansion of this protocol. The reactions were proceeded for all used aldehydes (Table 2). The desired products were isolated in good to excellent yields in short reaction times without any byproducts.

A proposed mechanism for the synthesis of DHPPs catalyzed by NEST was shown in Scheme 3. Initially, the condensation of hydrazine hydrate (4) and ethyl 
Table 1 Preparation of $5 \mathrm{~h}$ in the presence of NEST under various conditions

\begin{tabular}{|c|c|c|c|}
\hline Entry & $\begin{array}{l}\text { Conditions } \\
\text { Solvent/catalyst (g)/Temp. }\left({ }^{\circ} \mathrm{C}\right)\end{array}$ & Time (min) & Yield $^{\mathrm{a}}(\%)$ \\
\hline 1 & $\mathrm{H}_{2} \mathrm{O} / \mathrm{NEST}(0.06) / \mathrm{r.t}$ & 180 & 55 \\
\hline 2 & $\mathrm{H}_{2} \mathrm{O} / \mathrm{NEST}(0.06) /$ Reflux & 120 & 58 \\
\hline 3 & EtOH/NEST $(0.06) / r . t$ & 60 & 75 \\
\hline 4 & EtOH/NEST (0.06)/Reflux & 60 & 80 \\
\hline 5 & $\mathrm{H}_{2} \mathrm{O}: \mathrm{EtOH}(1: 1) / \mathrm{NEST}(0.06) / \mathrm{r.t}$ & 45 & 83 \\
\hline 6 & $\mathrm{H}_{2} \mathrm{O}: \mathrm{EtOH}(1: 1) / \mathrm{NEST}$ (0.06)/Reflux & 30 & 85 \\
\hline 7 & $-/$ NEST $(0.06) / 35$ & 90 & 77 \\
\hline 8 & -/NEST $(0.06) / 60$ & 150 & 70 \\
\hline 9 & $-/-/ r . t$ & 30 & 25 \\
\hline 10 & -/NEST $(0.02) / r . t$ & 45 & 85 \\
\hline 11 & -/NEST $(0.04) / r . t$ & 20 & 90 \\
\hline 12 & -/NEST $(0.06) /$ r.t & 15 & 94 \\
\hline 13 & -/NEST $(0.1) / r . t$ & 20 & 89 \\
\hline
\end{tabular}

Reaction was performed with ethyl acetoacetate $(1 \mathrm{mmol})$,

4-chlorobenzaldehyde $(1 \mathrm{mmol})$, malononitrile $(1 \mathrm{mmol})$, and hydrazine hydrate ( $2 \mathrm{mmol})$

a Isolated yield

acetoacetate (1) was formed intermediate (6) in the presence of NEST as a Lewis acid. The Knoevenagel condensation of malononitrile (3) with aromatic aldehyde (1) was produced the intermediate (8). Michael addition reaction of the intermediate $(\mathbf{8})$ and (7) were generated intermediate (10), followed by intramolecular cyclization and tautomerization have given the DHPPs (5).

In order to investigation of the catalyst reusability, after the reaction completion, the NEST was isolated by adding acetone to reaction mixture and then filtered. The recovered catalyst was washed with dichloromethane and dried at room temperature. It was observed that the recovered nanocatalyst could be used at least four times without significant loss of its catalytic activity (Fig. 6).

The structure of recovered catalyst was studied by FT-IR (Fig. 7) and TGA-DTA (Fig. 8). The comparison between fresh and recoverable catalysts have shown no differences.

Finally, the catalytic performance of NEST was compared with that of other previously reported catalysts for the synthesis of $5 \mathrm{a}$ (Table 3). From the viewpoints of green chemistry and simplicity, our method is a good one.

\section{Conclusion}

In this work, we have synthesized the NEST and characterized it as a novel heterogeneous natural nanocatalyst. This catalyst was used for the synthesis of DHPPs at room temperature under solvent free condition via condensation of hydrazine hydrate, ethyl acetoacetate, malononitrile, and aromatic aldehydes. This method includes some advantages such as the solvent-free condition, good to excellent yields, room temperature, short reaction time, easy work-up and reusability of the catalyst.

\section{Experimental section}

\section{Chemicals and apparatus}

All compounds were purchased from Merck, Aldrich and Fluka chemical companies. FT-IR spectra were run on a Bruker, Equinox 55 spectrometer. A Bruker (DRX-400 Avance) NMR was used to record the ${ }^{1} \mathrm{H}$ and ${ }^{13} \mathrm{C}$ NMR

Table 2 Synthesis of DHPPs 5(a-o) in the presence of NEST

\begin{tabular}{|c|c|c|c|c|c|c|}
\hline Entry & $\mathrm{Ar}$ & Product & Time (min) & Yield ${ }^{a}(\%)$ & $\mathrm{Mp}\left({ }^{\circ} \mathrm{C}\right)$ & Refs. \\
\hline 1 & $\mathrm{C}_{6} \mathrm{H}_{5}$ & $5 a$ & 10 & 92 & $242-244$ & [44] \\
\hline 2 & $2-\mathrm{OCH}_{3} \mathrm{C}_{6} \mathrm{H}_{4}$ & $5 b$ & 15 & 89 & $226-228$ & [45] \\
\hline 3 & $3-\mathrm{O}_{2} \mathrm{NC}_{6} \mathrm{H}_{4}$ & $5 c$ & 10 & 90 & $210-211$ & [45] \\
\hline 4 & $4-\mathrm{H}_{3} \mathrm{CC}_{6} \mathrm{H}_{4} 4$ & $5 d$ & 18 & 87 & 204-206 & [46] \\
\hline 5 & $4-\mathrm{O}_{2} \mathrm{NC}_{6} \mathrm{H}_{4}$ & $5 e$ & 9 & 93 & $239-242$ & {$[45]$} \\
\hline 6 & $3-\mathrm{BrC}_{6} \mathrm{H}_{4}$ & $5 f$ & 15 & 94 & $223-224$ & [46] \\
\hline 7 & $4-\mathrm{BrC}_{6} \mathrm{H}_{4}$ & $5 g$ & 12 & 96 & $178-180$ & {$[45]$} \\
\hline 8 & $4-\mathrm{ClC}_{6} \mathrm{H}_{5}$ & $5 \mathrm{~h}$ & 10 & 94 & $230-232$ & [44] \\
\hline 9 & $4-\mathrm{OHC}_{6} \mathrm{H}_{4}$ & $5 i$ & 10 & 95 & $222-224$ & [46] \\
\hline 10 & $3,4-(\mathrm{OH}) \mathrm{C}_{6} \mathrm{H}_{3}$ & $5 j$ & 10 & 91 & $225-227$ & [47] \\
\hline 11 & $2,4-(\mathrm{Cl}) \mathrm{C}_{6} \mathrm{H}_{3}$ & $5 k$ & 20 & 90 & $223-225$ & [46] \\
\hline 12 & $3-\mathrm{OCH}_{3} 4-\mathrm{OH}, \mathrm{C}_{6} \mathrm{H}_{3}$ & $5 I$ & 15 & 92 & $234-236$ & [46] \\
\hline 13 & $4-\mathrm{FC}_{6} \mathrm{H}_{4}$ & $5 m$ & 8 & 96 & $212-214$ & [45] \\
\hline 14 & 2-Furyl & $5 n$ & 10 & 91 & $228-230$ & [48] \\
\hline 15 & 1-Naphthyl & 50 & 25 & 88 & $206-208$ & {$[20]$} \\
\hline
\end{tabular}

a Isolated yield 


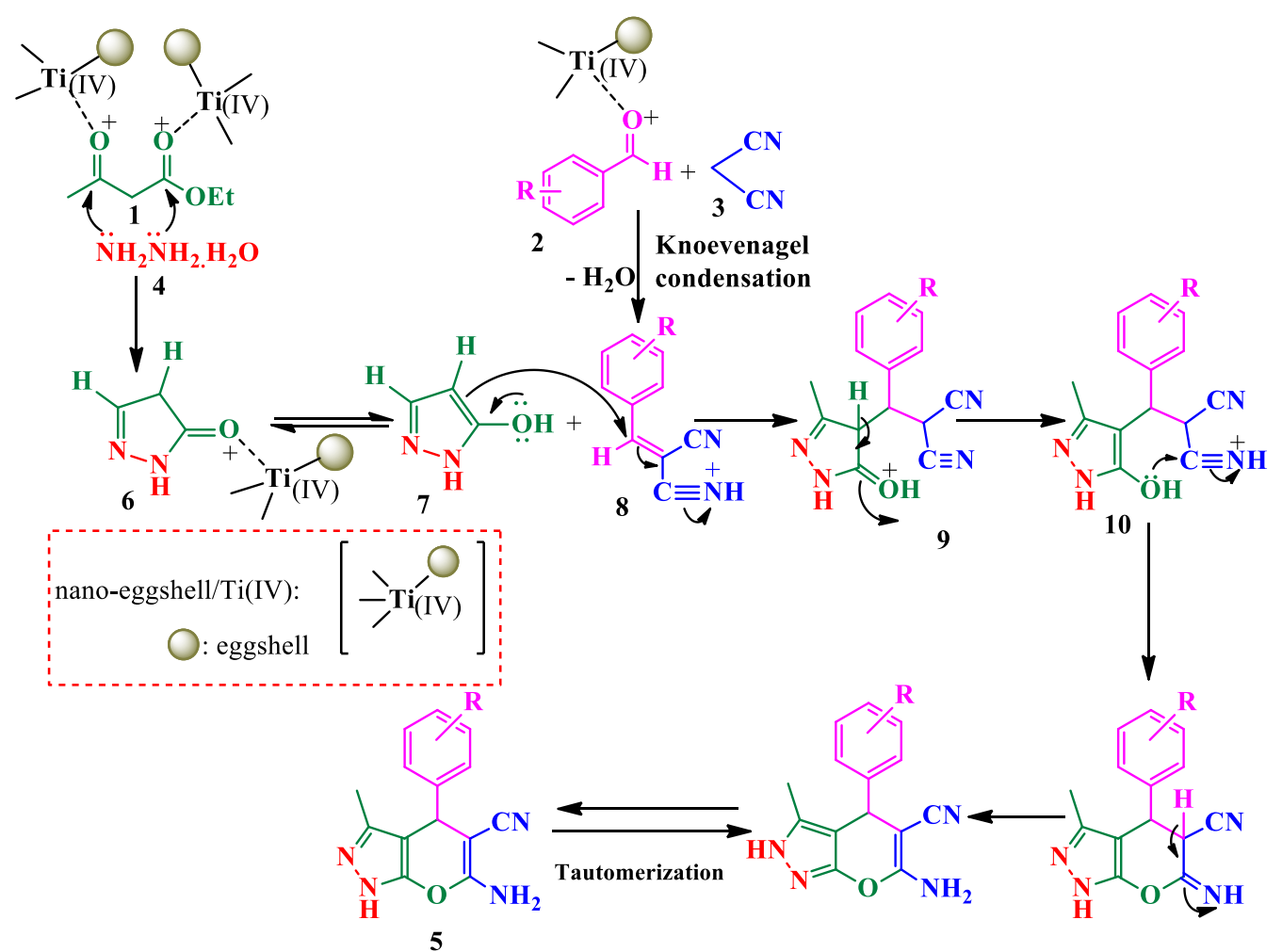

Scheme 3. Proposed mechanism for the synthesis of DHPPS

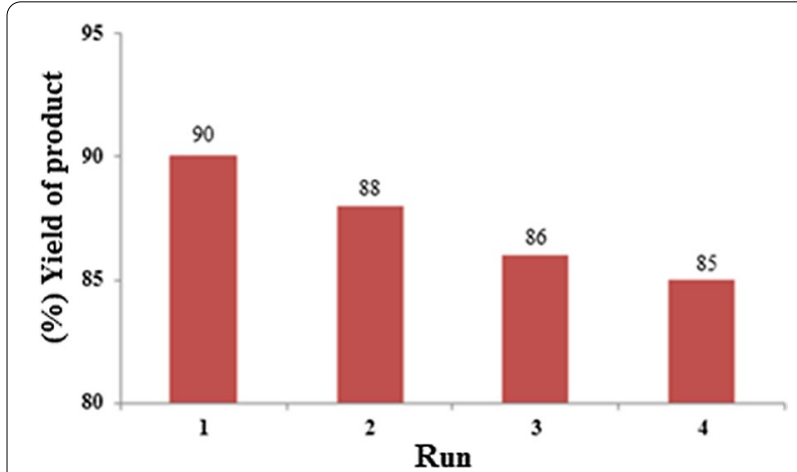

Fig. 6 Reusability of NEST

spectra. The morphology of the particles was observed by FESEM under acceleration voltage of $120 \mathrm{kV}$. The XRD patterns were obtained on a Philips Xpert MPD diffractometer $\left(\mathrm{Cu} \mathrm{Ka}\right.$, radiation, $\left.\mathrm{k}^{1 / 4} 0.154056 \mathrm{~nm}\right)$. EDS was obtained using a Phenom pro $\mathrm{X}$ instrument. TGA was conducted using STA 504 instrument.

\section{Preparation of NEST}

Firstly, the eggshell was heated in boiling water for $30 \mathrm{~min}$, dried in oven $150{ }^{\circ} \mathrm{C}$ and powdered. Then, $1 \mathrm{~g}$ of

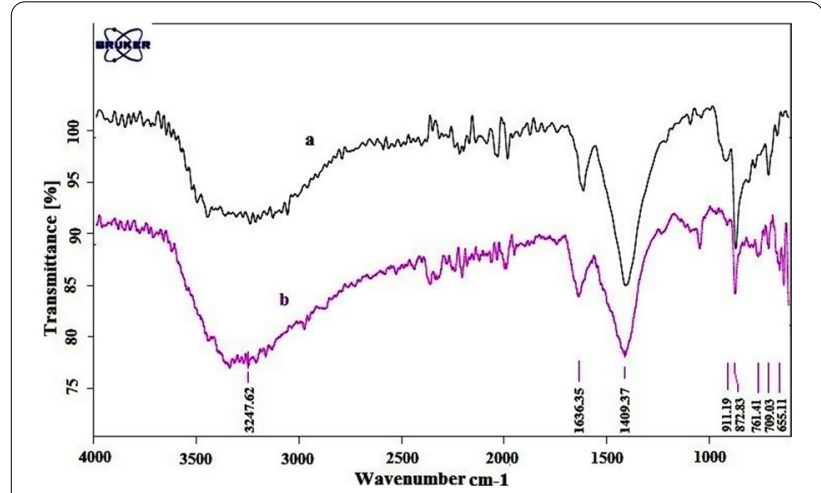

Fig. 7 FT-IR spectrum of $\mathbf{a}$ fresh NEST, $\mathbf{b}$ recovered NEST

prepared nano-eggshell powder was stirred for $30 \mathrm{~min}$ in $10 \mathrm{~mL}$ of dried $\mathrm{CH}_{2} \mathrm{Cl}_{2}$. Titanium tetrachloride $(4.36 \mathrm{~mL})$ was slowly added dropwise to the mixture. After stirring at room temperature for $30 \mathrm{~min}$, the resulting product filtered and washed with dichloromethane three times. Finally, the obtained NEST was dried at room temperature for $3 \mathrm{~h}$. 


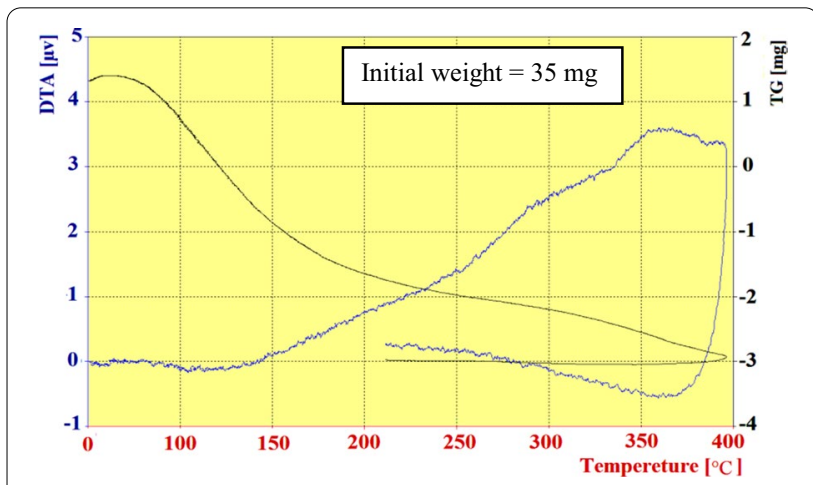

Fig. 8 TGA and DTA results of recovered NEST

Table 3 Catalytic performances of NEST in comparison with some other catalysts for synthesis of $5 a$

\begin{tabular}{llllll}
\hline Entry & Catalyst & Solvent & Temp $\left({ }^{\circ} \mathbf{C}\right)$ & Time (min) & $\begin{array}{l}\text { Yield } \\
{[\text { Refs. }}\end{array}$ \\
\hline 1 & $\mathrm{I}_{2}$ & $\mathrm{H}_{2} \mathrm{O}$ & r.t & 10 & $90[49]$ \\
2 & $\begin{array}{l}\text { Isonicotinic } \\
\text { acid }\end{array}$ & - & 80 & 10 & $92[50]$ \\
& & & & \\
3 & Piperidine & $\mathrm{H}_{2} \mathrm{O}$ & r.t & $5-10$ & $89[51]$ \\
4 & Y-Alumina & $\mathrm{H}_{2} \mathrm{O}$ & Reflux & 35 & $90[20]$ \\
5 & Et $_{3} \mathrm{~N}$ & $\mathrm{EtOH}$ & Reflux & 15 & $72[26]$ \\
6 & $\mathrm{NEST}^{\mathrm{b}}$ & - & r.t & 10 & 92 \\
\hline
\end{tabular}

${ }^{a}$ Isolated yield

b This work

\section{General procedure for the synthesis of DHPPs}

In a $100 \mathrm{~mL}$ round bottom flask, a mixture of aldehyde (1 mmol), malononitrile $(1 \mathrm{mmol})$, hydrazine hydrate $(2 \mathrm{mmol})$, ethyl acetoacetate $(1 \mathrm{mmol})$ and NEST $(0.06 \mathrm{~g})$ was stirred at room temperature. Progress of the reaction was monitored by TLC ( $n$-hexane:EtOAc, 4:1). After completion of the reaction, the mixture was dissolved in acetone. Then, the catalyst was filtered off and the obtained solution was poured into cold water. The obtained solid product was filtered and purified by recrystallization from ethanol and water (4:1). The obtained NEST catalyst was then washed with $\mathrm{EtOH}$, dried and reused directly for four times in other fresh reactions with negligible decreasing of the yields.

\section{Spectroscopic data for some products}

6-Amino-3-methyl-4-(3-nitrophenyl)-1,4-dihydropyrano[2,

\section{3-c]pyrazole-5-carbonitrile (Table 2, entry 3)}

White solid. M.P. $210-211{ }^{\circ} \mathrm{C}$ FT-IR (ATR)/ $\overline{\mathrm{v}}\left(\mathrm{cm}^{-1}\right)$ : 3484, 3231, 3120, 2190, 1645, 1597, 1519, 1491, 1410, 1351, 733. ${ }^{1} \mathrm{H}$ NMR $\left(400 \mathrm{MHz}\right.$, DMSO- $\left.\mathrm{d}_{6}\right) / \delta(\mathrm{ppm})$ : $1.82(\mathrm{~s}, 3 \mathrm{H}), 4.89(\mathrm{~s}, 1 \mathrm{H}), 7.08(\mathrm{~s}, 2 \mathrm{H}), 7.64-7.70(\mathrm{~m}, 2 \mathrm{H})$, $8.04(\mathrm{~s}, 1 \mathrm{H}), 8.13-8.15(\mathrm{~d}, J=8 \mathrm{~Hz}, 1 \mathrm{H}), 12.23(\mathrm{~s}, 1 \mathrm{H})$;
${ }^{13} \mathrm{C}$ NMR (100 MHz, DMSO-d 6 )/ $\delta$ ppm: 161.63, 155.17, $148.36,147.32,136.38,134.88,130.47,122.33,121.01$, 97.15, 56.59, 36.11, 10.25 .

\section{6-Amino-3-methyl-4-(4-nitrophenyl)-1,4-dihydropyrano[2, 3-c]pyrazole-5-carbonitrile (Table 2, entry 5)}

White solid. M.P. $239-242{ }^{\circ} \mathrm{C}$. FT-IR $($ ATR $) / \bar{v}\left(\mathrm{~cm}^{-1}\right)$ : 3475, 3227, 3106, 2195, 1646, 1592, 1513, 1399, 1348, 1163, 1109, 810, 744; ${ }^{1} \mathrm{H}$ NMR(400 MHz, Acetone$\left.\mathrm{d}_{6}\right) / \delta$ ppm: 2 (s, 3H), $4.88(\mathrm{~s}, 1 \mathrm{H}), 6.30$ (br s, $\left.2 \mathrm{H}\right), 7.55$ (d, $J=8 \mathrm{~Hz}, 2 \mathrm{H}), 8.23(\mathrm{~d}, J=8 \mathrm{~Hz}, 2 \mathrm{H}), 11.43(\mathrm{~s}, 1 \mathrm{H})$. ${ }^{13} \mathrm{C}$ NMR (100 MHz, DMSO-d 6 )/ $\delta$ ppm: $161.62,155.15$, $152.59,146.85,136.36,132.19,129.32,124.38,120.98$, $97.04,56.37,36.36,10.22$.

\section{6-Amino-4-(4-hydroxyphenyl)-3-me-}

thyl-1,4-dihydropyrano[2,3-c]pyrazole-5-carbonitrile (Table 2, entry 9)

White solid. M.P. $222-224{ }^{\circ} \mathrm{C}$. FT-IR (ATR)/ $\overline{\mathrm{v}}\left(\mathrm{cm}^{-1}\right)$ : 3372, 3304, 3127, 2173, 1645, 1594, 1510, 1489, 1441, 1404, 1189, 1166, 1041, 809. ${ }^{1} \mathrm{H}$ NMR $(400 \mathrm{MHz}$, Acetone $\left.-\mathrm{d}_{6}\right) / \delta(\mathrm{ppm}): 1.74(\mathrm{~s}, 3 \mathrm{H}), 4.44(\mathrm{~s}, 1 \mathrm{H}), 6.65$ (dd, $J=7.5 \mathrm{~Hz}, J=3.7 \mathrm{~Hz}, 2 \mathrm{H}), 6.76($ br s, $2 \mathrm{H}), 6.91(\mathrm{dd}$, $J=7.5 \mathrm{~Hz}, J=3.7 \mathrm{~Hz}, 2 \mathrm{H}), 9.27(\mathrm{~s}, 1 \mathrm{H}), 12.02(\mathrm{~s}, 1 \mathrm{H})$; ${ }^{13} \mathrm{C}$ NMR (100 MHz, DMSO-d 6 )/ $/$ ppm: 161.10, 156.49, $155.22,135.98,135.24,128.92,121.40,115.58,98.54$, $58.21,35.95,10.24$.

\section{6-Amino-4-(2,4-dichlorophenyl)-3-me- thyl-1,4-dihydropyrano[2,3-c]pyrazole-5-carbonitrile (Table 2, entry 11)}

Pale yellow solid. M.P. $223-225{ }^{\circ} \mathrm{C}$. FT-IR (ATR) $/ \bar{v}$ $\left(\mathrm{cm}^{-1}\right)$ : 3482, 3243, 3115, 2186, 1638, 1587, 1491, 1408, 1100, 1052, 866, 741.; ${ }^{1} \mathrm{H}$ NMR (400 MHz, DMSO$\left.\mathrm{d}_{6}\right) / \delta$ ppm: $1.85(\mathrm{~s}, 3 \mathrm{H}), 5.13(\mathrm{~s}, 1 \mathrm{H}), 7.07(\mathrm{~s}, 2 \mathrm{H}), 7.29$ (d, $J=8 \mathrm{~Hz}, 1 \mathrm{H}$ ), 7.47 (dd, $J=8.4 \mathrm{~Hz}, J=2 \mathrm{~Hz}, 1 \mathrm{H}), 7.65$ $(\mathrm{d}, J=2.4 \mathrm{~Hz}, 1 \mathrm{H}), 12.23(\mathrm{~s}, 1 \mathrm{H}) . ;{ }^{13} \mathrm{C}$ NMR $(100 \mathrm{MHz}$, DMSO-d ${ }_{6}$ )/ $\delta$ ppm: $161.30,154.88,140.07,135.44,132.81$, $132.10,128.83,128.02,120.25,96.32,55.21,33.07,9.53$.

\section{Abbreviations}

NEST: Nano-eggshell/Ti(IV); MCRs: Multi-component reactions; EtOH: Ethanol; FESEM: Field Emission Scanning Electron Microscope; FT-IR: Fourier Transform Infrared; XRD: X-ray diffraction; EDX: Energy-Dispersive X-ray; TGA: Thermo Gravimetric Analysis; NMR: Nuclear magnetic resonance; TLC: Thin layer chromatography.

\section{Acknowledgements}

The authors would like to thank Yazd University, Yazd, Iran

\section{Authors' contributions}

ADT and BFM designed and performed the research, analyzed the data, interpreted the results and prepared the manuscript. ADT performed the assay, conducted the optimization, purification of compounds. AB and NS revised the manuscript. All authors read and approved the final manuscript. 


\section{Funding}

This study was financially supported by Yazd University. The funding bodies played no role in the design of the study and collection, analysis, and interpretation of data and in writing the manuscript.

\section{Availability of data and materials}

All data generated or analysed during this study are included in this published article.

\section{Ethics approval and consent to participate}

Not applicable.

\section{Consent for publication}

Not applicable.

\section{Competing interests}

The authors declare that they have no competing interests.

\section{Author details}

1 Department of Chemistry, College of Science, Yazd University,

P.O.Box 89195-741, Yazd, I.R. of Iran. ${ }^{2}$ Department of Organic Chemistry, Faculty of Chemistry, University of Kashan, Kashan, I.R. of Iran.

Received: 20 August 2020 Accepted: 8 January 2021

Published online: 25 January 2021

\section{References}

1. Choudhary G, Peddinti RK (2011) An expeditious, highly efficient, catalystfree and solvent-free synthesis of nitroamines and nitrosulfides by Michael addition. Green Chem 13:276-282

2. Jain SL, Singhal S, Sain B (2007) PEG-assisted solvent and catalyst free synthesis of 3, 4-dihydropyrimidinones under mild reaction conditions. Green Chem 9:740-741

3. Metzger JO (1998) Solvent-free organic syntheses. Angew Chem Int Ed 37:2975-2978

4. Tavakolian M, Vahdati-Khajeh S, Asgari S (2019) Recent advances in solvent-free asymmetric catalysis. ChemCatChem 11:2943-2977

5. Rahman M, Sarkar A, Ghosh M, Majee A, Hajra A (2014) Catalytic application of task specific ionic liquid on the synthesis of benzoquinazolinone derivatives by a multicomponent reaction. Tetrahedron Lett 55:235-239

6. De Graaff C, Ruijter E, Orru RV (2012) Recent developments in asymmetric multicomponent reactions. Chem Soc Rev 41:3969-4009

7. Domling A, Wang W, Wang K (2012) Chemistry and biology of multicomponent reactions. Chem Rev 112:3083-3135

8. Hulme C, Chappeta S, Griffith C, Lee YS, Dietrich J (2009) An efficient solution phase synthesis of triazadibenzoazulenones:'designer isonitrile free'methodology enabled by microwaves. Tetrahedron Lett 50:1939-1942

9. Trost BM (1991) The atom economy-a search for synthetic efficiency. Science 254:1471-1477

10. Shen ZL, Ji SJ (2009) Alkali salt of L-proline as an efficient and practical catalyst for the cyanosilylation of a wide variety of carbonyl compounds under solvent-free conditions. Synth Commun 39:775-791

11. Tanaka K, Toda F (2000) Solvent-free organic synthesis. Chem Rev 100:1025-1074

12. Das D, Banerjee R, Mitra A (2014) Bioactive and pharmacologically important pyrano [2,3-c] pyrazoles. J Chem Pharm Res 6:108-116

13. Mandour A, El-Sawy E, Ebaid M, Hassan S (2012) Synthesis and potential biological activity of some novel 3-[(N-substituted indol-3-yl) methyleneamino]-6-amino-4-aryl-pyrano (2,3-c) pyrazole-5-carbonitriles and 3,6-diamino-4-(N-substituted indol-3-yl) pyrano (2,3-c) pyrazole5-carbonitriles. Acta Pharm 62:15-30

14. Zaki ME, Soliman HA, Hiekal OA, Rashad AE (2006) Pyrazolopyranopyrimidines as a class of anti-inflammatory agents. Z Naturforsch C 61:1-5

15. Mohamed NR, Khaireldin NY, Fahmyb AF, El-Sayeda AAF (2010) Facile synthesis of fused nitrogen containing heterocycles as anticancer agents. Der Pharm Chem 2:400-417
16. Nasr MN, Gineinah MM (2002) Pyrido [2,3-d] pyrimidines and pyrimido $\left[5^{\prime}, 4^{\prime}: 5,6\right]$ pyrido $[2,3-d]$ pyrimidines as new antiviral agents: synthesis and biological activity. Arch Pharm Int J Pharm Med Chem 335:289-295

17. Abdelrazek FM, Metz P, Metwally NH, El-Mahrouky SF (2006) Synthesis and molluscicidal activity of new cinnoline and pyrano [2,3-c] pyrazole derivatives. Arch Pharm Int J Pharm Med Chem 339:456-460

18. Foloppe N, Fisher LM, Howes R, Potter A, Robertson AG, Surgenor AE (2006) Identification of chemically diverse Chk1 inhibitors by receptorbased virtual screening. Bioorg Med chem 14:4792-4802

19. Junek H, Aigner H (1973) Synthesen mit nitrilen, XXXV. Reaktionen von tetracyanäthylen mit heterocyclen. Chem Ber 106:914-921

20. Mecadon H, Rohman MR, Rajbangshi M, Myrboh B (2011) $\gamma$-Alumina as a recyclable catalyst for the four-component synthesis of 6-amino-4-alkyl/ aryl-3-methyl-2,4-dihydropyrano [2,3-c] pyrazole-5-carbonitriles in aqueous medium. Tetrahedron lett 52:2523-2525

21. Reddy MM, Jayashankara VP, Pasha MA (2010) Glycine-catalyzed efficient synthesis of pyranopyrazoles via one-pot multicomponent reaction. Synth Commun 40:2930-2934

22. Ebrahimi J, Mohammadi A, Pakjoo V, Bahramzade E, Habibi A (2012) Highly efficient solvent-free synthesis of pyranopyrazoles by a Brønsted-acidic ionic liquid as a green and reusable catalyst. J Chem Sci 124:1013-1017

23. Mecadon H, Rohman MR, Kharbangar I, Laloo BM, Kharkongor I, Rajbangshi M, Myrboh B (2011) L-Proline as an efficicent catalyst for the multi-component synthesis of 6-amino-4-alkyl/aryl-3-methyl-2,4-dihydropyrano $[2,3-c]$ pyrazole-5-carbonitriles in water. Tetrahedron Lett 52:3228-3231

24. Siddekha A, Nizam A, Pasha MA (2011) An efficient and simple approach for the synthesis of pyranopyrazoles using imidazole (catalytic) in aqueous medium, and the vibrational spectroscopic studies on 6-amino-4-(4'methoxyphenyl)-5-cyano-3-methyl-1-phenyl-1,4-dihydropyrano [2,3-c] pyrazole using density functional theory. Spectrochim Acta A 81:431-440

25. Reddy MB, Pasha MA (2012) One-pot, multicomponent synthesis of $4 \mathrm{H}$-pyrano $[2,3-\mathrm{C}]$ pyrazoles in water at $25^{\circ} \mathrm{C}$. Indian J Chem Sect B 51:537-541

26. Litvinov YM, Shestopalov AA, Rodinovskaya LA, Shestopalov AM (2009) New convenient four-component synthesis of 6-amino-2,4-dihydropyrano $[2,3-c]$ pyrazol-5-carbonitriles and one-pot synthesis of $6^{\prime}$-aminospiro [(3H)-indol-3,4'-pyrano [2,3-c] pyrazol]-(1H)-2-on-5'-carbonitriles. J Comb Chem 11:914-919

27. Zolfigol MA, Yarie M (2017) $\mathrm{Fe}_{3} \mathrm{O}_{4} @ \mathrm{TiO}_{2} @ \mathrm{O}_{2} \mathrm{PO}_{2}\left(\mathrm{CH}_{2}\right) \mathrm{NHSO}_{3} \mathrm{H}$ as a novel nanomagnetic catalyst: application to the preparation of 2-amino-4,6-diphenylnicotinonitriles via anomeric-based oxidation. Appl Organomet Chem 31:e3598

28. Shokouhimehr M, Piao Y, Kim J, Jang Y, Hyeon T (2007) A magnetically recyclable nanocomposite catalyst for olefin epoxidation. Angew Chem Int Ed 46:7039-7043

29. Kwon SG, Hyeon T (2008) Colloidal chemical synthesis and formation kinetics of uniformly sized nanocrystals of metals, oxides and chalcogenides. Acc Chem Res 41:1696-1709

30. Cai X, Wang H, Zhang Q, Tong J, Lei Z (2014) Magnetically recyclable core-shell Fe $\mathrm{O}_{4} @$ @hitosan-Schiff base complexes as efficient catalysts for aerobic oxidation of cyclohexene under mild conditions. J Mol Catal A Chem 383:217-224

31. Polshettiwar V, Varma RS (2010) Green chemistry by nano-catalysis. Green Chem 12:743-754

32. Krishna DSR, Siddharthan A, Seshadri SK, Kumar TS (2007) A novel route for synthesis of nanocrystalline hydroxyapatite from eggshell waste. J Mater Sci Mater Med 18:1735-1743

33. Mirjalili BF, Zolfigol MA, Bamoniri A, Hazar A (2005) $\mathrm{Al}\left(\mathrm{HSO}_{4}\right)_{3}$ as an efficient catalyst for acetalization of carbonyl compounds under heterogeneous or solvent-free conditions. J Brazil Chem Soc 16:877-880

34. Mirjalili BF, Hashemi MM, Sadeghi B, Emtiazi $\mathrm{H}$ (2009) $\mathrm{SnCl} / \mathrm{SiO}_{2}$ : an efficient heterogeneous alternative for one-pot synthesis of $\beta$-acetamidoketones. J Chin Chem Soc 56:386-391

35. Safajoo N, Mirjalili BF, Bamoniri A (2019) $\mathrm{Fe}_{3} \mathrm{O}_{4} @$ nano-cellulose/Cu(II): a bio-based and magnetically recoverable nano-catalyst for the synthesis of 4 -pyrimido $[2,1-b]$ benzothiazole derivatives. RSC Adv 9:1278-1283

36. Salehi N, Mirjalili BF (2017) Synthesis of highly substituted dihydro2-oxopyrroles using $\mathrm{Fe}_{3} \mathrm{O}_{4} @$ nano-cellulose- $\mathrm{OPO}_{3} \mathrm{H}$ as a novel bio-based magnetic nanocatalyst. RSC Adv 7:30303-30309 
37. Azad S, Mirjalili BF (2016) $\mathrm{Fe}_{3} \mathrm{O}_{4} @$ nano-cellulose/TiCl: a bio-based and magnetically recoverable nano-catalyst for the synthesis of pyrimido $[2,1$ b] benzothiazole derivatives. RSC Adv 6:96928-96934

38. Mirjalili BF, Reshquiyea RZ (2015) $\mathrm{BF}_{3}$ /nano-sawdust as a green, biodegradable and inexpensive catalyst for the synthesis of highly substituted dihydro-2-oxopyrroles. RSC Adv 5:15566-15571

39. Su C, Suarez DL (1995) Coordination of adsorbed boron: a FTIR spectroscopic study. Environ Sci Technol 29:302-311

40. Ahmad R, Kumar R, Haseeb S (2012) Adsorption of $\mathrm{Cu}^{2+}$ from aqueous solution onto iron oxide coated eggshell powder: evaluation of equilibrium, isotherms, kinetics, and regeneration capacity. Arab J Chem 5:353-359

41. Valbe R, Tarkanovskaja M, Mäeorg U, Reedo V, Hoop A, Kink I, Lõhmus A (2014) Elaboration of hybrid cotton fibers treated with an ionogel/carbon nanotube mixture using a sol-gel approach. Open Chem 13:279-286

42. Zhu Y, Zhang L, Gao C, Cao L (2000) The synthesis of nanosized $\mathrm{TiO}_{2}$ powder using a sol-gel method with $\mathrm{TiCl}_{4}$ as a precursor. J Mater Sci 35:4049-4054

43. Keller OL (1963) Identification of complex ions of niobium (V) in hydrofluoric acid solutions by Raman and infrared spectroscopy. Inorg Chem 2:783-787

44. Aliabadi RS, Mahmoodi NO (2016) Green and efficient synthesis of pyranopyrazoles using $[\mathrm{bmim}]\left[\mathrm{OH}^{-}\right]$as an ionic liquid catalyst in water under microwave irradiation and investigation of their antioxidant activ ity. RSC Adv 6:85877-85884

45. Moosavi-Zare AR, Zolfigol MA, Salehi-Moratab R, Noroozizadeh E (2016) Catalytic application of 1-(carboxymethyl) pyridinium iodide on the synthesis of pyranopyrazole derivatives. J Mol Catal A Chem 415:144-150
46. Huang X, Li Z, Wang D, LiY (2016) Bovine serum albumin: an efficient and green biocatalyst for the one-pot four-component synthesis of pyrano [2,3-c] pyrazoles. Chin J Catal 37:1461-1467

47. Tameh FA, Safaei-Ghomi J, Mahmoudi-Hashemi M, Shahbazi-Alavi H (2016) One-pot multicomponent reaction synthesis of spirooxindoles promoted by guanidine-functionalized magnetic $\mathrm{Fe}_{3} \mathrm{O}_{4}$ nanoparticles. RSC Adv 6:74802-74811

48. Pore DM, Patil PB, Gaikwad DS, Hegade PG, Patil JD, Undale KA (2013) Green access to novel spiro pyranopyrazole derivatives. Tetrahedron Lett 54:5876-5878

49. Muramulla S, Zhao CG (2011) A new catalytic mode of the modularly designed organocatalysts (MDOs): enantioselective synthesis of dihydropyrano [2,3-c] pyrazoles. Tetrahedron Lett 52:3905-3908

50. Zolfigol MA, Tavasoli M, Moosavi-Zare AR, Moosavi P, Kruger HG, Shiri M, Khakyzadeh V (2013) Synthesis of pyranopyrazoles using isonicotinic acid as a dual and biological organocatalyst. RSC Adv 3:25681-25685

51. Vasuki G, Kumaravel K (2008) Rapid four-component reactions in water: synthesis of pyranopyrazoles. Tetrahedron Lett 49:5636-5638

\section{Publisher's Note}

Springer Nature remains neutral with regard to jurisdictional claims in published maps and institutional affiliations.
Ready to submit your research? Choose BMC and benefit from:

- fast, convenient online submission

- thorough peer review by experienced researchers in your field

- rapid publication on acceptance

- support for research data, including large and complex data types

- gold Open Access which fosters wider collaboration and increased citations

- maximum visibility for your research: over $100 \mathrm{M}$ website views per year

At BMC, research is always in progress.

Learn more biomedcentral.com/submissions 